\title{
FORMULATION AND EVALUATION OF BILAYER TABLET CONTAINING DICLOFENAC SODIUM AS SUSTAINED RELEASE AND ALOE VERA GEL POWDER AS IMMEDIATE RELEASE
}

\author{
HARSHAD PADEKAR*, OMKAR LOHOTE \\ VJSM's Vishal Institute of Pharmaceutical Education and Research Ale, Tal-Junnar Dist-Pune (412411) \\ Email: harshadpadekar@gmail.com
}

Received: 15 Apr 2019, Revised and Accepted: 13 Jun 2019

\begin{abstract}
Objective: The objective of the present investigation is to design formulate and characterized the bilayer tablet containing Diclofenac sodium and Aloe Vera gel powder. In which diclofenac sodium is sustained release and Aloe Vera gel powder is immediate release. In order to produce a single dosage form containing two different classes, drug are widely prescribed by the physician to have better patient compliance.

Methods: Bilayer tablet was prepared by direct compression, The immediate release layer of Aloe Vera gel powder was prepared by using different excipients such as starch, sodium starch glycolate, lactose, talc etc. sustained release layer of diclofenac sodium was prepared by using HPMC K4M, lactose, Talc Magnesium stearate, talc etc. for preparation of bilayer tablet sodium starch glycolate are use as super disintegrants in immediate release tablet and HPMC K4M are use as controlled release polymer. Various Preformulation parameter i.e. Identification, melting point, compatibility study, solubility are checked. Micromeritics properties of powder blend such as bulk density, tapped density, hausner's ratio, Carr's index, angle of repose are performed. Post-compression parameter was done such as hardness, friability, weight variation, drug content uniformity, thickness, in vitro drug release.
\end{abstract}

Results: Result was found within the limit of the standard of optimized formulation. The drug release of the tablet was in the range of $82 \mathrm{to} 92 \% \mathrm{in} 8 \mathrm{~h}$.

Conclusion: Bilayer tablet was prepared by optimized batches of both layers. The prepared tablets showed satisfactory results for various evaluation parameters. The optimized formulation based on all the parameter A1 (Sodium starch glycolate) is selected for the immediate release layer and D3 (HPMC K4M) was selected for the controlled release layer. The drug release mechanism was found to be zero order release depends upon diffusion.

Keywords: Bilayer tablet, Diclofenac sodium, Aloe Vera gel powder, HPMC K4M, Immediate release, Sustained release, Direct compression

(C) 2019 The Authors. Published by Innovare Academic Sciences Pvt Ltd. This is an open access article under the CC BY license (http://creativecommons.org/licenses/by/4.0/) DOI: http://dx.doi.org/10.22159/ijcpr.2019v11i4.34923

\section{INTRODUCTION}

The purpose of any drug delivery system is to provide a therapeutic amount of the drug to the proper site of action in the body to maintain the desired drug concentration. Oral rout is most convenient route of the administration dosage form. Tablet is a convenient dosage form acceptable by patients and physicians. Bilayer tablet is suitable for sequential release of two drugs in which one is immediate release and another is sustained release [1]. The fixed-dose Combinations of two or more active drugs produced in a single dosage form. The advantages of combination therapy to reduce the number of the dosage form in prescription and maintain administrative cost as well as improving patient compliance. The present study is about to find out the solution to reduce the incidence of diclofenac sodium-induced GI injury and other severe GI problems. This problem is overcome by preparing the bilayer tablet of diclofenac sodium with Aloe vera gel powder. Diclofenac sodium is a non-steroidal anti-inflammatory drug which has analgesic and antipyretic activity. Diclofenac is used to treat pain, menstrual pain, dysmenorrhea, ocular inflammation, osteoarthritis, rheumatoid arthritis and ankylosing spondylitis. The primary mechanism responsible for its analgesic, anti-inflammatory and antipyretic action is inhibition of prostaglandin synthesis by inhibition of cyclooxygenase and it appears to inhibit DNA synthesis. Inhibition of COX also decreases prostaglandins in the epithelium of the stomach, making it more sensitive to corrosion by gastric acid, which is responsible for the cause of ulcer [2]. Diclofenac is absorbed $100 \%$ orally, $99 \%$ protein bound, metabolized and excreted both in urine and bile. The elimination half-life is 1.2 to $2 \mathrm{~h}$ hence, diclofenac is suitable for sustained release layer [3]. Aloe Vera Gel Powder is the natural anti-ulcer medicine. Which Acts by directly interact with the $\mathrm{H}^{2}$ receptor on parietal cells which is responsible for decreases gastric acid secretion by direct interaction with acid. It is a poorly soluble drug with a short biological half-life of $4 \mathrm{hr}$ and its absorption from the gastrointestinal tract (GIT) is rate limited [4] hence aloe vera choose for immediate release. Present study is to prepared bilayer tablets of
Diclofenac Sodium (SR) by using HPMC as controlled release polymer in sustained release layer along with other excipients and aloe vera gel powder (IR) using SSG super disintegrants in an immediate release [5]. Both layers are compressed by direct compression methods. To evaluate blends in terms of Angle of repose, Bulk and tapped density, Carr's index, Hausner's Ratio and to evaluate Bi-layer matrix tablets in terms of hardness, weight variation, friability, thickness, drug content uniformity, In vitro dissolution studies in 1.2 and $6.8 \mathrm{pH}$ [6].

\section{MATERIALS AND METHODS}

\section{Material}

Sample was procuring from Diclofenac sodium 0, HPMC K4M, Talc (Thermosil fine chem.) Aloe vera gel powder (maple biotech pvt ltd bhosari, Pune) starch, sodium starch glycolate, (research lab) Lactose, (Sahyadri scientific supply) Magnesium Stearate (Hilab chemicals) were sample is analytical grade.

\section{Method}

Formulation of bilayer tablet was prepared by direct compression method. Immediate release layer was prepared by using different super disintegrants (sodium starch glycolate).

Drug and above super disintegrants were passed through the $40 \#$ sieve and transfer into polybag and mix up to 3 min. Then add other excipients to the above mixture. Finally, add (glidant) talc into the blend.

Another layer was also prepared by direct compression; drug and polymer (HPMC k4M) were pass through the $40 \#$ sieve transfer into polybag and mixed properly up to $3 \mathrm{~min}$. Other excipients were mixed well and finally added Magnesium Stearate in the above blend and were mixed for $2 \mathrm{~min}$.

Finally above optimized batch blends were compressed by rotary tablet compression machine (Make-CREATE INDUSTRIES, MODEL-LP8GMP). 
Table 1: Formulation of immediate release aloe vera gel powder

\begin{tabular}{|c|c|c|c|c|}
\hline \multirow[t]{2}{*}{ S. No. } & \multirow[t]{2}{*}{ Ingridients } & \multicolumn{3}{|c|}{ Weight (mg) } \\
\hline & & A1 & A2 & A3 \\
\hline 1 & Aloe Vera gel Powder & 100 & 100 & 100 \\
\hline 2 & Starch & 7 & 8 & 9 \\
\hline 3 & SSG & 5 & 4 & 3 \\
\hline 4 & Lactose & 33 & 33 & 33 \\
\hline 5 & Talc & 5 & 5 & 5 \\
\hline \multirow[t]{2}{*}{6} & Color & q. $s$ & q. $s$ & q. $s$ \\
\hline & Total & 150 & 150 & 150 \\
\hline
\end{tabular}

Table 2: Formulation of sustained release diclofenac sodium

\begin{tabular}{|c|c|c|c|c|}
\hline \multirow[t]{2}{*}{ S. No. } & \multirow[t]{2}{*}{ Ingridients } & \multicolumn{3}{|c|}{ Weight (mg) } \\
\hline & & D1 & D2 & D3 \\
\hline 1 & Diclofenac sodium & 50 & 50 & 50 \\
\hline 2 & HPMC K4M & 12 & 20 & 28 \\
\hline 3 & Lactose & 128 & 120 & 112 \\
\hline 4 & Talc & 5 & 5 & 5 \\
\hline \multirow[t]{2}{*}{5} & Magnesium stearate & 5 & 5 & 5 \\
\hline & Total & 200 & 200 & 200 \\
\hline
\end{tabular}

\section{Preformulation study: $[7,8]$}

\section{Identification test by $\mathrm{U}$. $\mathrm{V}$ vis. spectrophotometer}

\section{A. For diclofenac sodium:}

$25 \mathrm{mg}$ of diclofenac sodium was weighed accurately and transferred it to $25 \mathrm{ml}$ volumetric flask. Dissolved it in ethanol and make the volume up to $25 \mathrm{ml}$ with respective solvent. This was considered a stock solution $(1000 \mathrm{mcg} / \mathrm{ml})$. Further dilutions were made with this stock solution and scanned in the range of 400-200 nm using respective blank in UV spectrophotometer (SHIMADZU U. V 1800).

\section{B. For Aloe vera gel powder}

$25 \mathrm{mg}$ Aloe vera gel powder was weighed accurately and transferred it to $25 \mathrm{ml}$ volumetric flask. Dissolved it in methanol and make the volume up to $25 \mathrm{ml}$ with respective solvent. This was considered a stock solution $(1000 \mathrm{mcg} / \mathrm{ml})$. Further dilutions were made with this stock solution and scanned in the range of 400-200 nm using respective blank in UV spectrophotometer.

\section{Melting point determination [8]}

Melting point of diclofenac sodium and aloe vera gel powder was determined by using melting point apparatus by capillary method.

\section{Determination of solubility [8]}

\section{Qualitative Solubility}

Qualitative solubility analysis of drugs was done by dissolving $5 \mathrm{mg}$ of drug in $5 \mathrm{ml}$ solvent such as distilled water, methanol, ethanol, chloroform, phosphate buffer (7.4), ether.

\section{Compatibility study, by FT-IR spectroscopy [7]}

The powdered substance of the tablet was mix, dried potassium bromide (IR grade) ratio of sample is should be 1:100 $\mathrm{mg}$, i. e $1 \mathrm{mg}$ sample: $100 \mathrm{mg} \mathrm{KBr}$. are compressed to form transparent pellets. The sample was scanned from 4000 to $400 \mathrm{~cm}^{-1}$ at ambient temperature. (Perkin Elmer Spectrum-65)

\section{Pre-compression evaluation [7]}

\section{Bulk density}

Bulk density was determined by introducing the power blend into measuring cylinder and the total volume was measured and also total powder weight was measured. The bulk density was calculated by using formula.

Bulk density $(\mathrm{BD})=$ weight of powder/bulk volume.

\section{Tapped density}

Tapped density was determined by tapping the cylinder by using the tapped density apparatus. Tapped the cylinder up to 100 times and then measure the tapped volume and calculate the tapped density by using formula.

Tapped Density (TD) = weight of powder/tapped volume.

\section{Hausner's ratio}

Hausner's ratio bulk density as to tapped density is the number that is correlated to the flowability of a powder or powder blend. It is calculated using formula,

Hausner's ratio $=$ tapped density $/$ bulk density.

\section{Compressibility index}

Compressibility index was calculated by formula,

Carr's index (\%) = Tapped density-bulk density/tapped density* 100

\section{Angle of repose}

The angle of repose of powder blend of each layer of each formulation was determined by fix funnel method. The blend was poured through funnel separately until apex of pile so formed just touch the tip of the funnel. The angle of repose was calculated by using formula

$$
\theta=\tan ^{-1} \mathrm{~h} / \mathrm{r}
$$

$h$ is height of pile; $r$ is the radius of pile.

\section{Post-compression evaluation [6] \\ Uniformity weight}

Uniformity weight of the tablet was determined by selecting 20tablet randomly. This selected tablet weighing individually and the weight of individual tablet was compared with average weight.

\section{Thickness}

Thickness of the tablet was measured by using vernier calliper. 5 tablets were selected and thickness was measured in (mm).

Table 3: Limits for tablet weight variation test

\begin{tabular}{ll}
\hline Average weight of tablet (mg) & \% Difference allowed \\
\hline 130 or less & $10 \%$ \\
From 130 to 324 & $7.5 \%$ \\
$>324$ & $5 \%$ \\
\hline
\end{tabular}




\section{Hardness}

Hardness is an important parameter of evaluation of tablet. The resistance of the tablet to break under the condition of handling, transportation and storage depend upon hardness. The hardness of the tablet was measured by using Monsanto hardness tester. The unit of hardness is expressed in term of $\mathrm{kg} / \mathrm{cm}^{2}$.

\section{Friability}

Friction and shock are the forces that most often cause tablets to chip, cap or break. 10 tablets are weighed and placed in the (roche friabilator) apparatus they are exposed to rolling and repeated shocks as they fall 6 inches in each turn within the apparatus. After four minutes of this treatment or 100 revolutions, the tablets are weighed and the weight compared with the initial weight. The loss due to abrasion is a measure of the tablet friability. A maximum weight loss of not more than $1 \%$ of the weight of the tablets being tested during the friability test is considered generally acceptable and any broken or smashed tablets are not picked. The percentage friability was determined by the formula:

$\%$ friability $=\left[\right.$ initial weight-final weight $/$ initial weight ${ }^{*} 100$

\section{Content uniformity}

\section{For diclofenac sodium}

10 tablets were taken and crushed into morter to form a powder. From that, sample equivalent to $50 \mathrm{mg}$ of drug was taken and transferred to $100 \mathrm{ml}$ volumetric flask. Ethanol $(20 \mathrm{ml})$ was added dissolve the drug and volume were made up to mark with methanol, this was filtered. From the filtrate $1 \mathrm{ml}$ was taken and diluted with $\mathrm{pH} 6.8$ phosphate buffer and absorbance of this solution was measured by using $\mathrm{U}$. V-spectrophotometer at $275 \mathrm{~nm}$ (SHIMADZU; U. V1800).

\section{For aloe vera gel powder}

10 tablets were taken and crushed into morter to form a powder. From that, sample equivalent to $100 \mathrm{mg}$ of drug was taken and transferred to $100 \mathrm{ml}$ volumetric flask. Methanol $(20 \mathrm{ml})$ was added dissolve the drug and volume were made up to mark with methanol, this was filtered. From the filterate $1 \mathrm{ml}$ was taken and diluted with $\mathrm{pH} 6.8$ phosphate buffer and absorbance of this solution was measured by using $\mathrm{U}$. V-spectrophotometer at $262 \mathrm{~nm}$ (SHIMADZU; U. V1800).

\section{In vitro drug dissolution studies}

\section{In vitro drug release was studied for immediate release tablet (Aloe vera gel powder)}

In vitro drug release was studied using USP II (paddle) apparatus, (Electrolab TDT-08L) with $900 \mathrm{ml}$ of dissolution medium maintained at $37 \pm 1{ }^{\circ} \mathrm{C}$ for $15 \mathrm{~h}$, at $50 \mathrm{rpm} .0 .1 \mathrm{~N} \mathrm{HCl}(\mathrm{pH} 1.2) .5 \mathrm{ml}$ of sample was withdrawn in 10 min time intervals. The volume withdrawn at each interval was replaced with same quantity of fresh dissolution medium. Collected samples were analyzed by U. V spectrophotometrically at 262 $\mathrm{nm}$, and cumulative percent drug release was calculated.

\section{In vitro drug release was studied for sustained release tablet} (Diclofenac sodium)

The In vitro dissolution study for the Diclofenac sodium sustained release tablets were carried out in USP type-II dissolution test apparatus (Electrolab TDT-08L) (Paddle type) using $900 \mathrm{ml}$ of phosphate buffer $\mathrm{pH} 6.8$ at $50 \mathrm{rpm}$ and temperature $37 \pm 0.5{ }^{\circ} \mathrm{C}$. At predetermined time intervals, $5 \mathrm{ml}$ of the samples were withdrawn by means of a syringe fitted with a pre-filter, the volume withdrawn at each interval was replaced with same quantity of fresh dissolution medium. The resultant samples were analyzed by measuring the absorbance at $275 \mathrm{~nm}$ using UV Visible spectrophotometer and calculate the percentage drug release.

\section{In vitro drug release was studied for bilayer tablet}

The release of bilayer tablets was determined using USP Type II (Paddle) dissolution apparatus (Electrolab TDT-08L) under sink condition. The dissolution medium was $900 \mathrm{ml}$ of a $0.1 \mathrm{~N} \mathrm{HCl}$ solution $(\mathrm{pH}=1.2)$, at $370 \mathrm{c} \pm 0.20 \mathrm{c}$ for 1 hour. Then dissolution media replace by phosphate buffer $(6.8 \mathrm{pH})$. The stirring speed was $50 \mathrm{rpm}$. Aliquot of the solution was collected at the specific interval were replaced with fresh dissolution medium. The Aloe vera gel powder and Diclofenac sodium were analyzed spectrophotometrically at 262 $\mathrm{nm}$ and $275 \mathrm{~nm}$ respectively using simultaneous equation method.

\section{RESULTS AND DISCUSSION}

\section{Pre-formulation studies}

The UV absorption of $10 \mu \mathrm{g} / \mathrm{ml}$ in methanol for Aloe vera gel powder is $262 \mathrm{~nm}$ in the range of $200-400 \mathrm{~nm}$ exhibit maximum and in case of Diclofenac sodium at $275 \mathrm{~nm}$.

Melting point, solubility and compatibility study of both drugs are carried out and the result is including in table 4 .

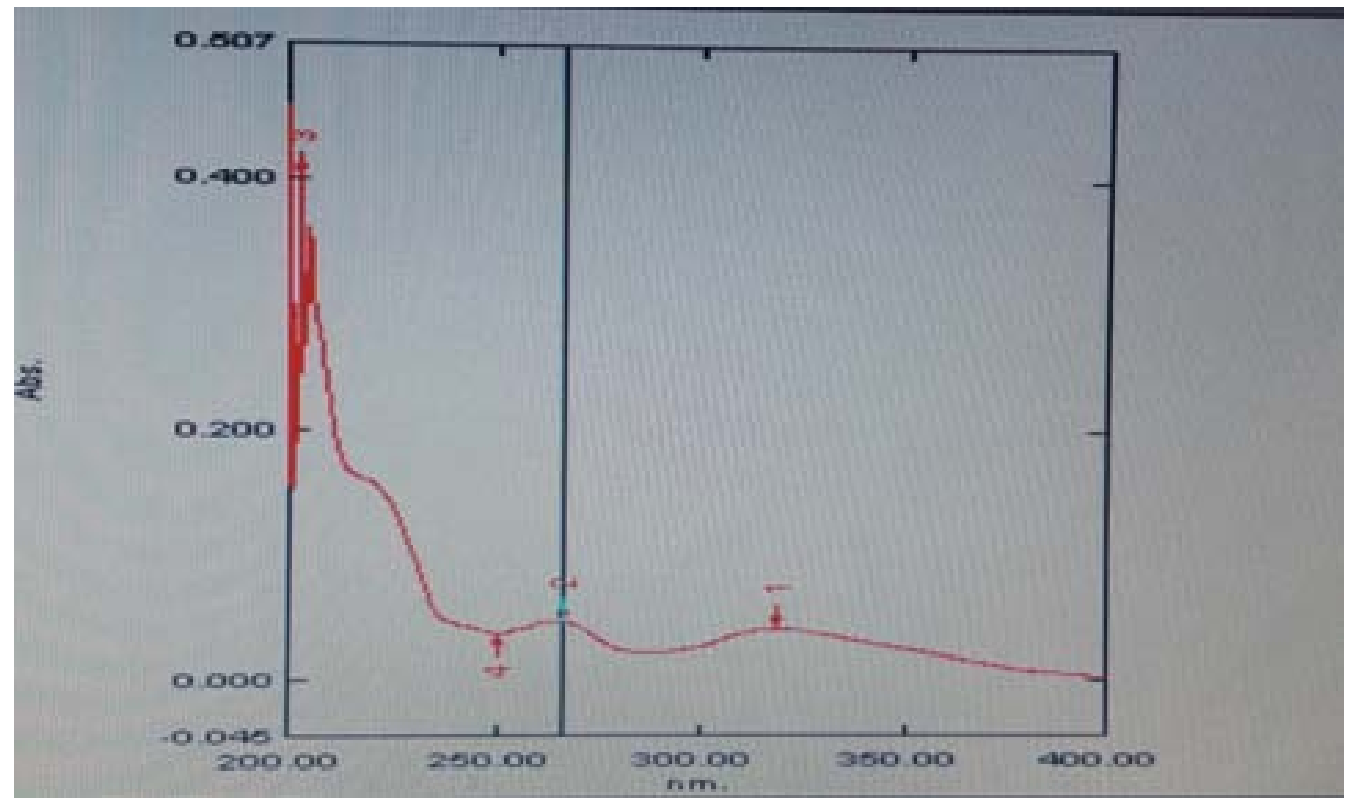

Fig. 1: Absorbance maxima of aloe vera gel powder 


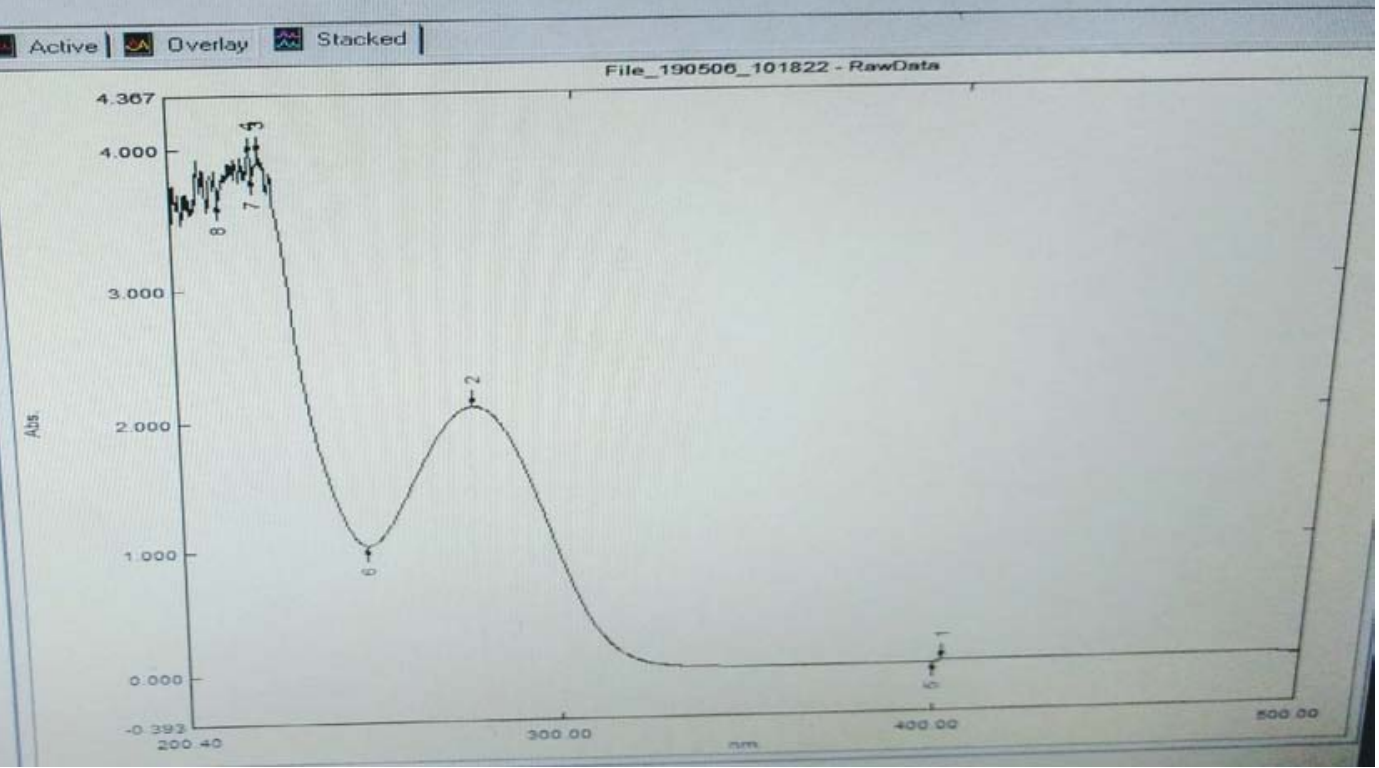

Fig. 2: Absorbance maxima of diclofenac sodium

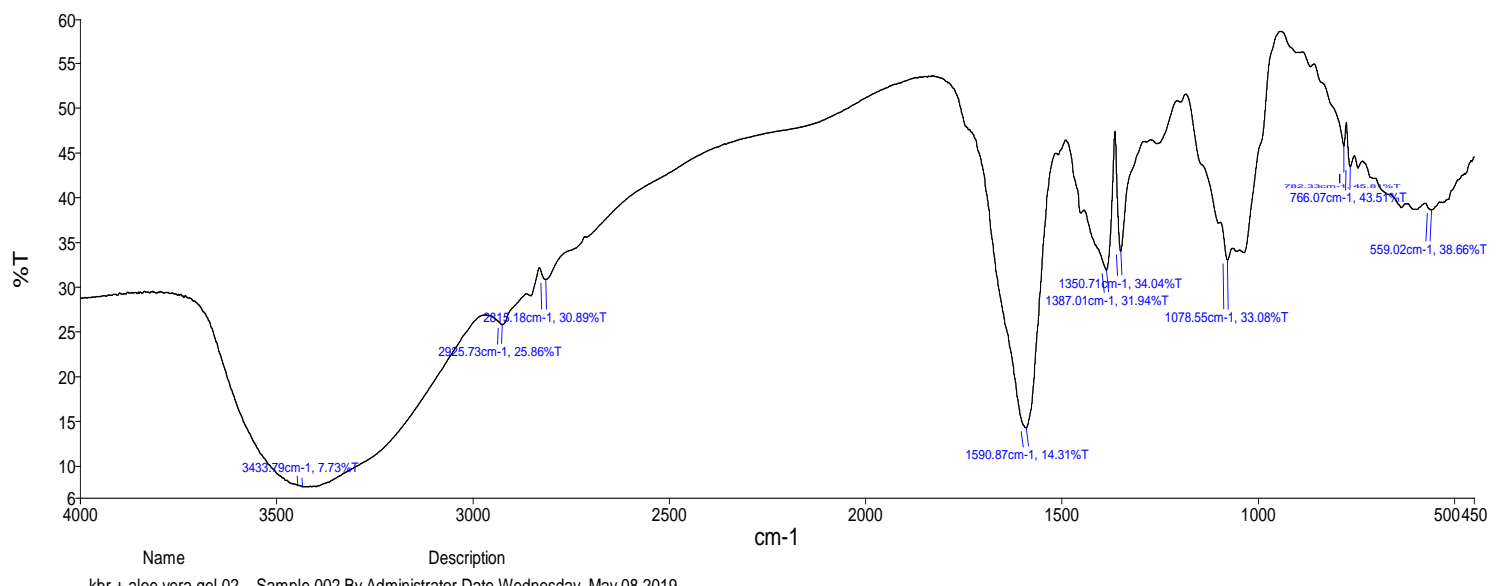

Fig. 3: FTIR of Aloe vera gel powder

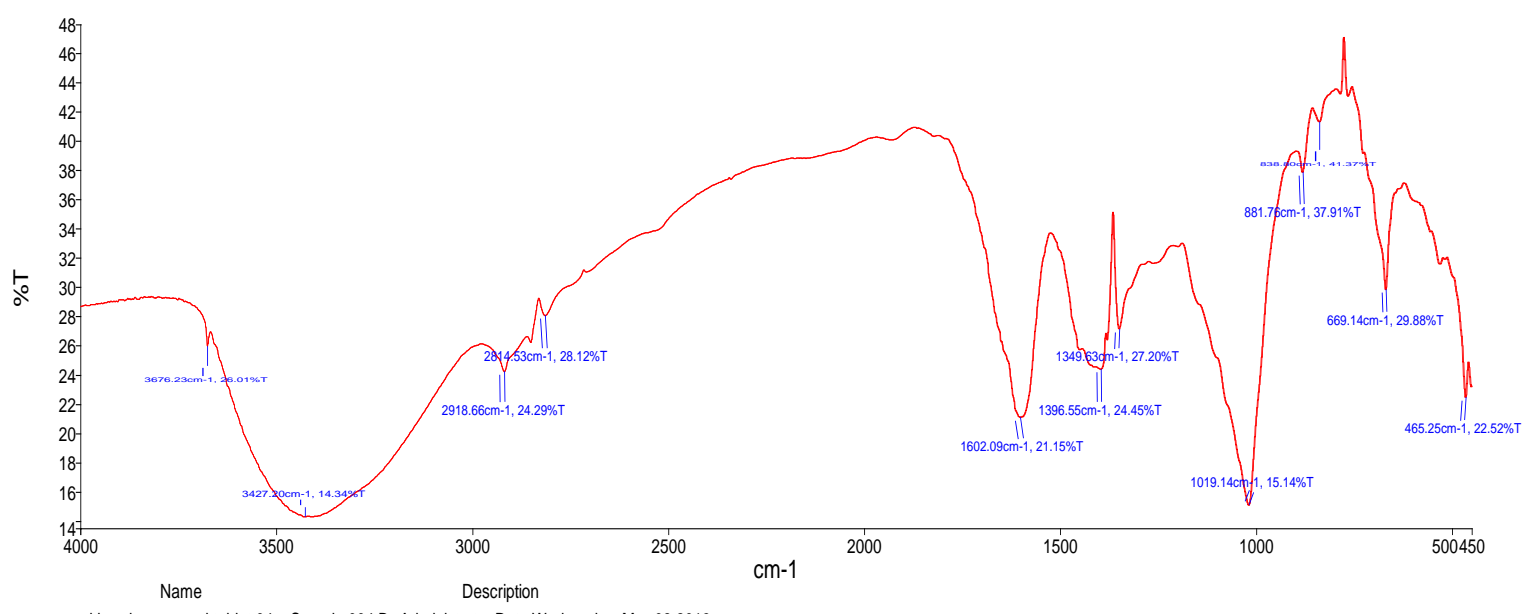

Fig. 4: FTIR of Aloe vera gel powder tablet 


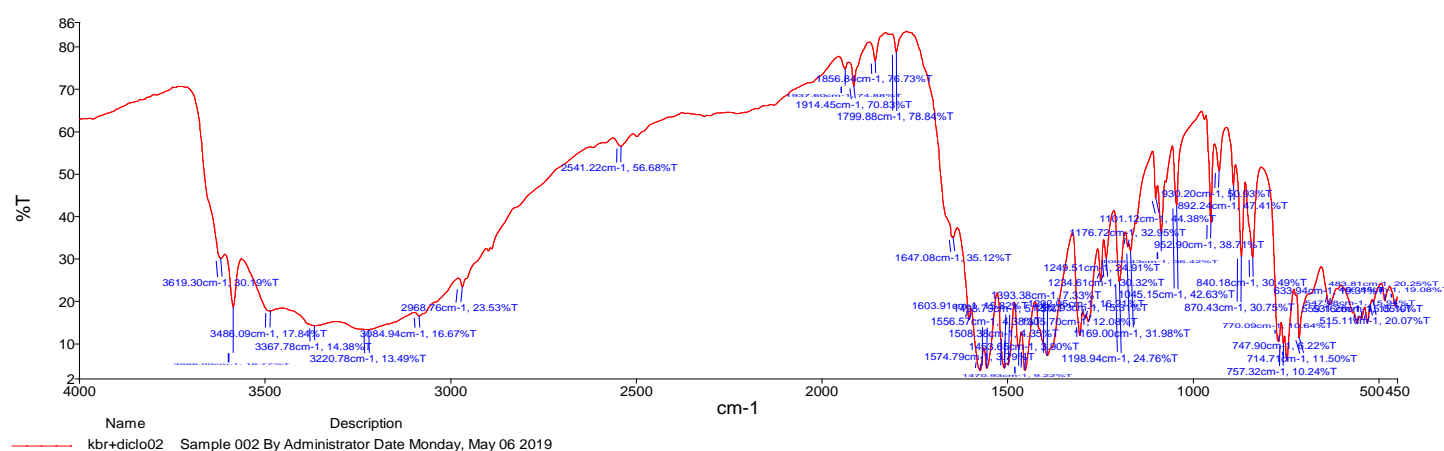

Fig. 5: FTIR of diclofenac sodium

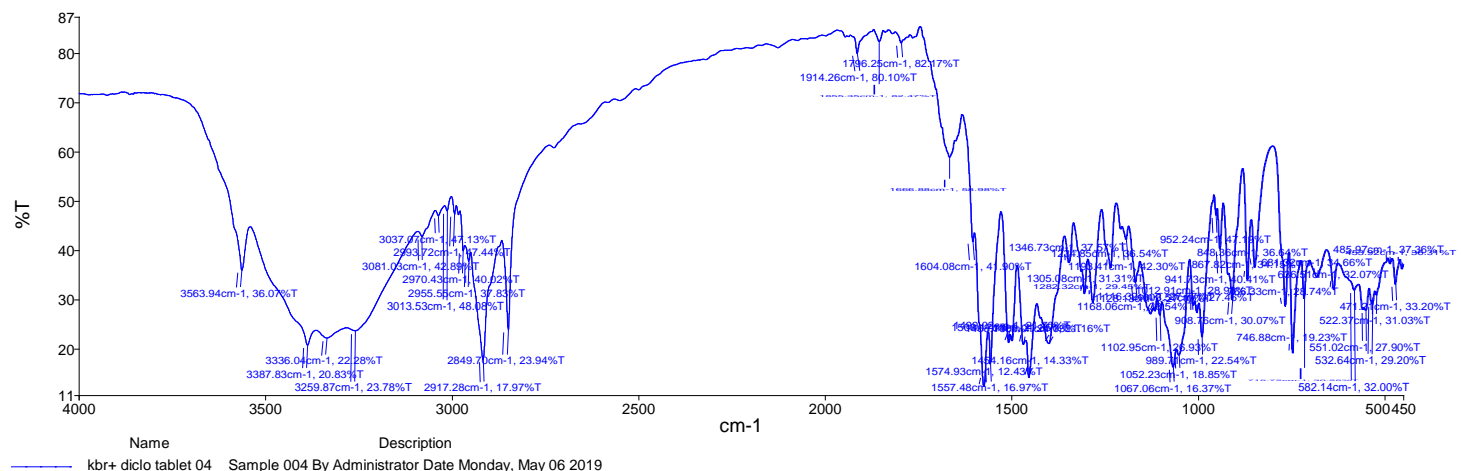

Fig. 6: FTIR of diclofenac sodium tablet

Table 4: Preformulation study of aloe vera gel powder and Diclofenac sodium

\begin{tabular}{llll}
\hline S. No. & Parameter & Aloe vera gel powder & Diclofenac sodium \\
\hline 1 & $\begin{array}{l}\text { Identification by U. V Vis } \\
\text { spectrophotometer. }\end{array}$ & $262 \mathrm{~nm}(\Lambda \max )$ & $275 \mathrm{~nm}(\Lambda \mathrm{max})$ \\
& Melting Point & $224{ }^{\circ} \mathrm{C}$ & $289{ }^{\circ} \mathrm{C}$ \\
3 & Solubility & $\begin{array}{l}\text { Highly Soluble in water, ethanol, methanol, } \\
\text { phosphate buffer, poorly soluble in chloroform. }\end{array}$ & $\begin{array}{l}\text { Soluble in water, methanol, ethanol, phosphate buffer, } \\
\text { insoluble in ether sparingly soluble in acetone. } \\
\text { Compatible }\end{array}$ \\
\hline
\end{tabular}

\section{Pre-compression evaluation}

The micromeritic properties such as of bulk density, tapped density, Angle of repose, compressibility index, and Hausner's of Aloe vera gel powder immediate release layer blend and Diclofenac sodium sustained release layer were studied. The overall results were shown in table No5. The value of bulk density indicates good packing characteristics. The compressibility index of the formulation Indicating poor flow properties of powder which were further confirmed by determining the angle of repose, it is in the range of $16^{\circ}$ to $26^{\circ}$ which indicates good flow properties.

Table 5: Pre-compression evaluation of immediate release powder blend (Aloe vera gel powder)

\begin{tabular}{|c|c|c|c|c|}
\hline S. No. & Parameter & A1 & A2 & A3 \\
\hline 1 & Bulk density (g/ml) & 64.36 & 66.10 & 61.94 \\
\hline 2 & Tapped density $(\mathrm{g} / \mathrm{ml})$ & 75.23 & 78.63 & 73.80 \\
\hline 3 & Compressibility index (\%) & $14.44 \%$ & $15.93 \%$ & $16.07 \%$ \\
\hline 4 & Hausner's ratio & 1.16 & 1.18 & 1.19 \\
\hline 5 & Angle of repose (degree) & $22.6^{\circ}$ & $24.90^{\circ}$ & $24.63^{\circ}$ \\
\hline
\end{tabular}

Table 6: Pre-compression evaluation of sustained release powder blend, (diclofenac sodium)

\begin{tabular}{llll}
\hline S. No. & Parameter & D1 & D2 \\
\hline 1 & Bulk density (g/ml) & 56.67 & 60.5 \\
2 & Tapped density (g/ml) & 68.1 & 69.6 \\
3 & Compressibility index (\%) & $16.1 \%$ & $13.07 \%$ \\
4 & Hausner's ratio & 1.20 & 66.70 \\
5 & Angle of repose (degree) & $20^{\circ}$ & 1.16 \\
\end{tabular}

\section{Post-compression evaluation of tablet}

The prepared tablets were evaluated for weight variation, dissolution test, thickness, hardness uniformity of dosage units and friability. The weight variation test is done by weighing 20 tablets individually, calculating the average weight and comparing the individual weights to the average. 
The hardness of each batch of the tablet was checked by using Monsanto hardness tester. The hardness was measured in terms of $\mathrm{kg} / \mathrm{cm} 2$. The hardness of 6 tablets was determined using

The Friability was determined by first weighing 10 tablets after dusting and placing them in a friability tester (Roche friabilator), which was rotated for $4 \mathrm{~min}$ at $25 \mathrm{rpm}$. After dusting, the total remaining mass of tablet was recorded and the percent friability was calculated.

The thickness of the each 10 tablets was measured with the Varnier Caliper. All test value are included. Drug content uniformity and In vitro drug release determined according to the USP requirements. Test values are including in table 9.

Table 7: Post-compression evaluation of immediate release tablet

\begin{tabular}{|c|c|c|c|c|}
\hline S. No. & Parameter & A1 & A2 & A3 \\
\hline 1 & Uniformity weight(mg) & $149 \mathrm{mg}$ & $147 \mathrm{mg}$ & $153 \mathrm{mg}$ \\
\hline 2 & Thickness(mm) & 3.0 & 3.1 & 3.0 \\
\hline 3 & Hardness $\left(\mathrm{kg} / \mathrm{cm}^{2}\right)$ & $3.2 \mathrm{~kg} / \mathrm{cm}^{2}$ & $3 \mathrm{~kg} / \mathrm{cm}^{2}$ & $3.5 \mathrm{~kg} / \mathrm{cm}^{2}$ \\
\hline 4 & Friability (\%) & $0.84 \%$ & $0.67 \%$ & $0.91 \%$ \\
\hline 5 & Drug content & 97.54 & 98.10 & 96.92 \\
\hline 6 & \% Drug release & $90.21 \%$ & $89.75 \%$ & $87.82 \%$ \\
\hline
\end{tabular}

Table 8: Post-compression evaluation of sustained release tablet

\begin{tabular}{|c|c|c|c|c|}
\hline S. No. & Parameter & A1 & A2 & A3 \\
\hline 1 & Uniformity weight(mg) & $199 \mathrm{mg}$ & $203 \mathrm{mg}$ & $201 \mathrm{mg}$ \\
\hline 2 & Thickness(mm) & 3.5 & 3.5 & 3.7 \\
\hline 3 & Hardness $\left(\mathrm{kg} / \mathrm{cm}^{2}\right)$ & $6.5 \mathrm{~kg} / \mathrm{cm}^{2}$ & $7 \mathrm{~kg} / \mathrm{cm}^{2}$ & $6.2 \mathrm{~kg} / \mathrm{cm}^{2}$ \\
\hline 4 & Friability (\%) & $0.54 \%$ & $0.91 \%$ & $0.80 \%$ \\
\hline 5 & Drug content & 95.40 & 91.50 & 96.92 \\
\hline 6 & \% Drug release & $91.21 \%$ & $86.35 \%$ & $82.12 \%$ \\
\hline
\end{tabular}

Table 9: Post-compression evaluation of bilayer tablet of A1 and D3 Optimized batch

\begin{tabular}{lll}
\hline S. No. & Parameter & A1D3 \\
\hline 1 & Uniformity weight(mg) & $349 \mathrm{mg}$ \\
2 & Thickness(mm) & $3.5 \mathrm{~mm}$ \\
3 & Hardness $\left(\mathrm{kg} / \mathrm{cm}^{2}\right)$ & $5.2 \mathrm{~kg} / \mathrm{cm}^{2}$ \\
4 & Friability (\%) & $0.90 \%$ \\
5 & Drug content (immediate release) & 97.21 \\
& Drug content (Sustained release) & 95.49 \\
6 & \% drug release (immediate release) & $93.80 \%$ \\
& \% drug release (Sustained release) & $84.26 \%$ \\
\hline
\end{tabular}

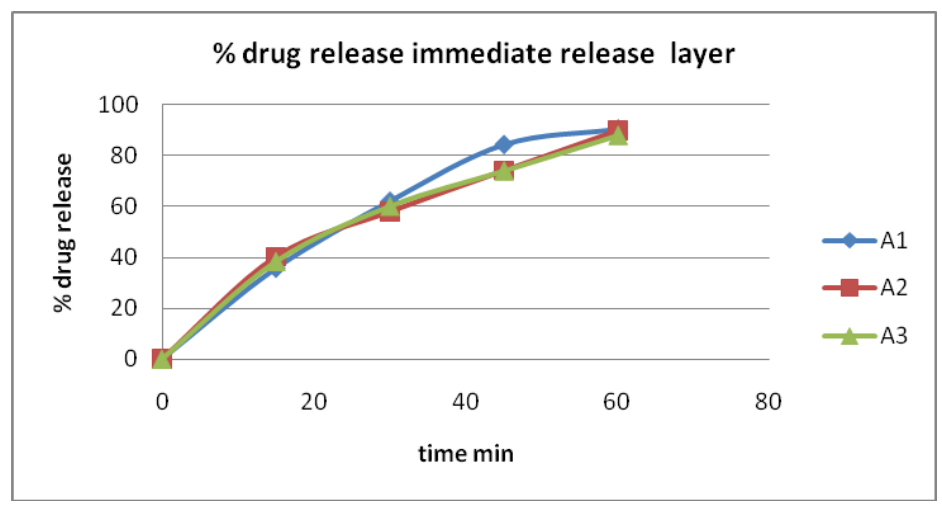

Fig. 7: \% Drug release immediate release layer (Aloe vera gel powder)

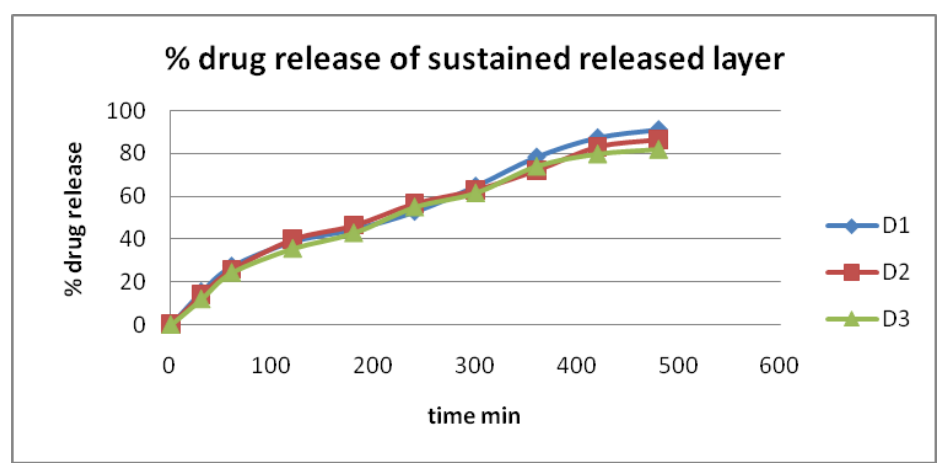

Fig. 8: \% Drug release of the sustained released layer (diclofenac sodium) 


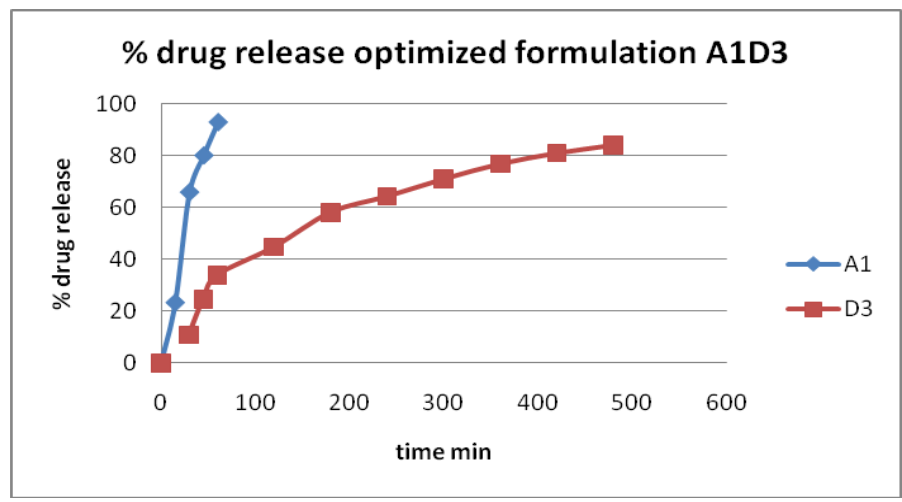

Fig. 9: \% Drug release optimized formulation A1, D3

Table 10: Drug release kinetics of Aloe vera gel powder

\begin{tabular}{|c|c|c|c|c|c|c|c|c|c|}
\hline Time (H) & $\begin{array}{l}\text { cumulative } \% \\
\text { drug released }\end{array}$ & $\begin{array}{l}\text { \% drug } \\
\text { remaining }\end{array}$ & $\begin{array}{l}\text { Square } \\
\text { root } \\
\text { time }\end{array}$ & $\begin{array}{l}\text { log cumu \% } \\
\text { drug remaining }\end{array}$ & $\begin{array}{l}\log \\
\text { time }\end{array}$ & $\begin{array}{l}\log \text { Cumu \% } \\
\text { drug } \\
\text { released }\end{array}$ & $\begin{array}{l}\% \text { Drug } \\
\text { released }\end{array}$ & $\begin{array}{l}\text { Cube root of \% } \\
\text { drug remaining } \\
\text { (Wt) }\end{array}$ & $\begin{array}{l}\text { Wo- } \\
\text { Wt }\end{array}$ \\
\hline 0 & 0 & 100 & 0.000 & 2.000 & 0.000 & 0.000 & 100 & 4.642 & 0.000 \\
\hline 15 & 20.5 & 79.5 & 3.873 & 1.900 & 1.176 & 1.312 & 20.5 & 4.300 & 0.342 \\
\hline 30 & 66 & 34 & 5.477 & 1.531 & 1.477 & 1.820 & 45.5 & 3.240 & 1.402 \\
\hline 45 & 80.2 & 19.8 & 6.708 & 1.297 & 1.653 & 1.904 & 14.2 & 2.705 & 1.937 \\
\hline 60 & 93.01 & 6.99 & 7.746 & 0.844 & 1.778 & 1.969 & 12.81 & 1.912 & 2.730 \\
\hline
\end{tabular}
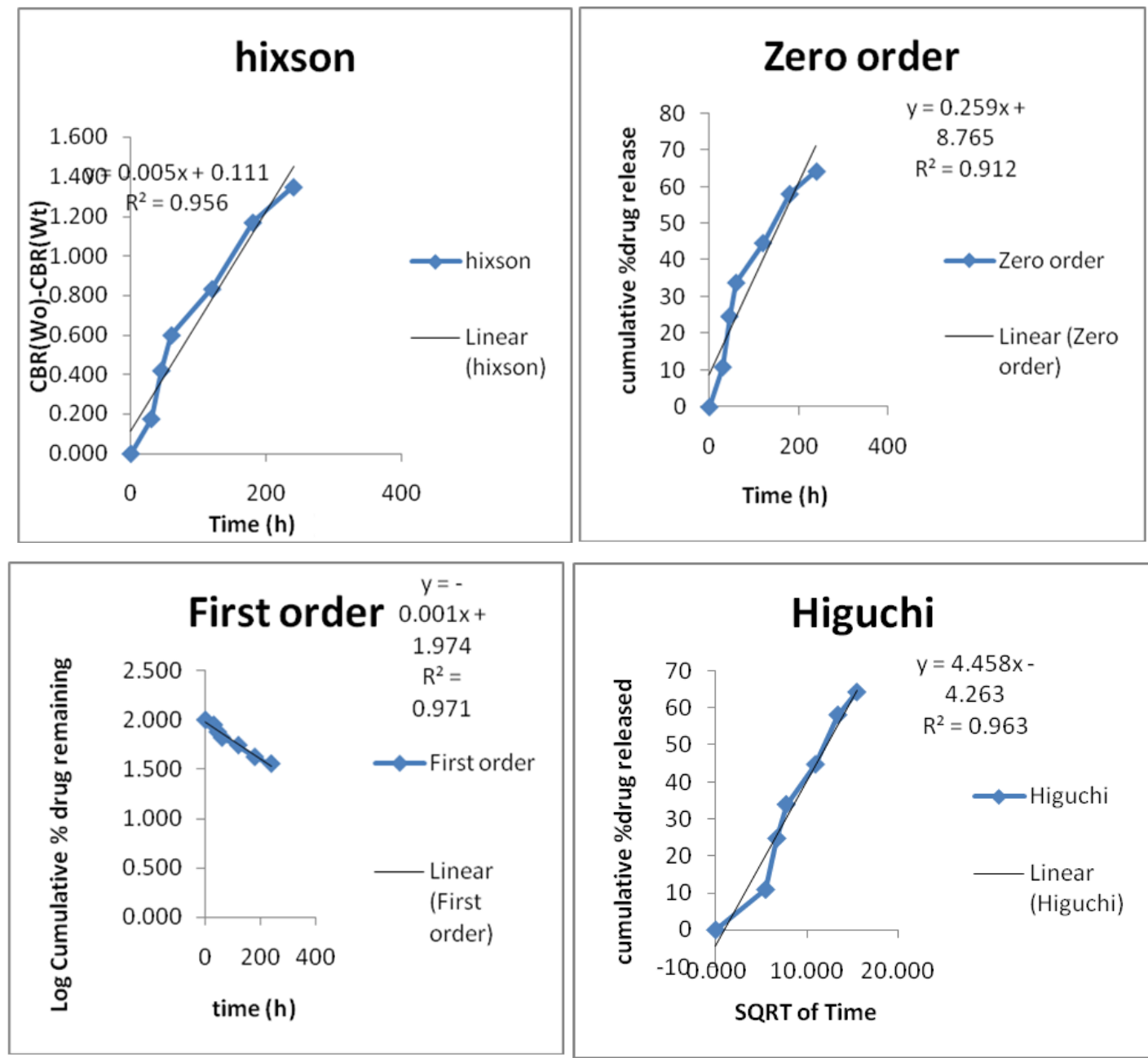

Fig. 10: Drug release kinetic of immediate release layer (Aloe vera gel) 
Table 11: Drug release kinetics of diclofenac sodium

\begin{tabular}{|c|c|c|c|c|c|c|c|c|c|}
\hline Time (H) & $\begin{array}{l}\text { Cumulative \% } \\
\text { drug released }\end{array}$ & $\begin{array}{l}\text { \% drug } \\
\text { remaining }\end{array}$ & $\begin{array}{l}\text { Square } \\
\text { root } \\
\text { time }\end{array}$ & $\begin{array}{l}\text { log cumu \% } \\
\text { drug } \\
\text { remainining }\end{array}$ & $\begin{array}{l}\text { log } \\
\text { time }\end{array}$ & $\begin{array}{l}\text { log cumu \% } \\
\text { drug } \\
\text { released } \\
\end{array}$ & $\begin{array}{l}\text { \% Drug } \\
\text { released }\end{array}$ & $\begin{array}{l}\text { Cube root of \% } \\
\text { drug remaining } \\
\text { (Wt) }\end{array}$ & $\begin{array}{l}\text { Wo- } \\
\text { Wt }\end{array}$ \\
\hline 0 & 0 & 100 & 0.000 & 2.000 & 0.000 & 0.000 & 100 & 4.642 & 0.000 \\
\hline 30 & 10.92 & 89.08 & 5.477 & 1.950 & 1.477 & 1.038 & 10.92 & 4.466 & 0.176 \\
\hline 45 & 24.73 & 75.27 & 6.708 & 1.877 & 1.653 & 1.393 & 13.81 & 4.222 & 0.420 \\
\hline 60 & 33.92 & 66.08 & 7.746 & 1.820 & 1.778 & 1.530 & 9.19 & 4.043 & 0.599 \\
\hline 120 & 44.75 & 55.25 & 10.954 & 1.742 & 2.079 & 1.651 & 10.83 & 3.809 & 0.833 \\
\hline 180 & 58.12 & 41.88 & 13.416 & 1.622 & 2.255 & 1.764 & 13.37 & 3.473 & 1.169 \\
\hline 240 & 64.28 & 35.72 & 15.492 & 1.553 & 2.380 & 1.808 & 6.16 & 3.293 & 1.349 \\
\hline 300 & 70.97 & 29.03 & 17.321 & 1.463 & 2.477 & 1.851 & 6.69 & 3.073 & 1.569 \\
\hline 360 & 76.83 & 23.17 & 18.974 & 1.365 & 2.556 & 1.886 & 5.86 & 2.851 & 1.791 \\
\hline 420 & 80.98 & 19.02 & 20.494 & 1.279 & 2.623 & 1.908 & 4.15 & 2.669 & 1.973 \\
\hline
\end{tabular}
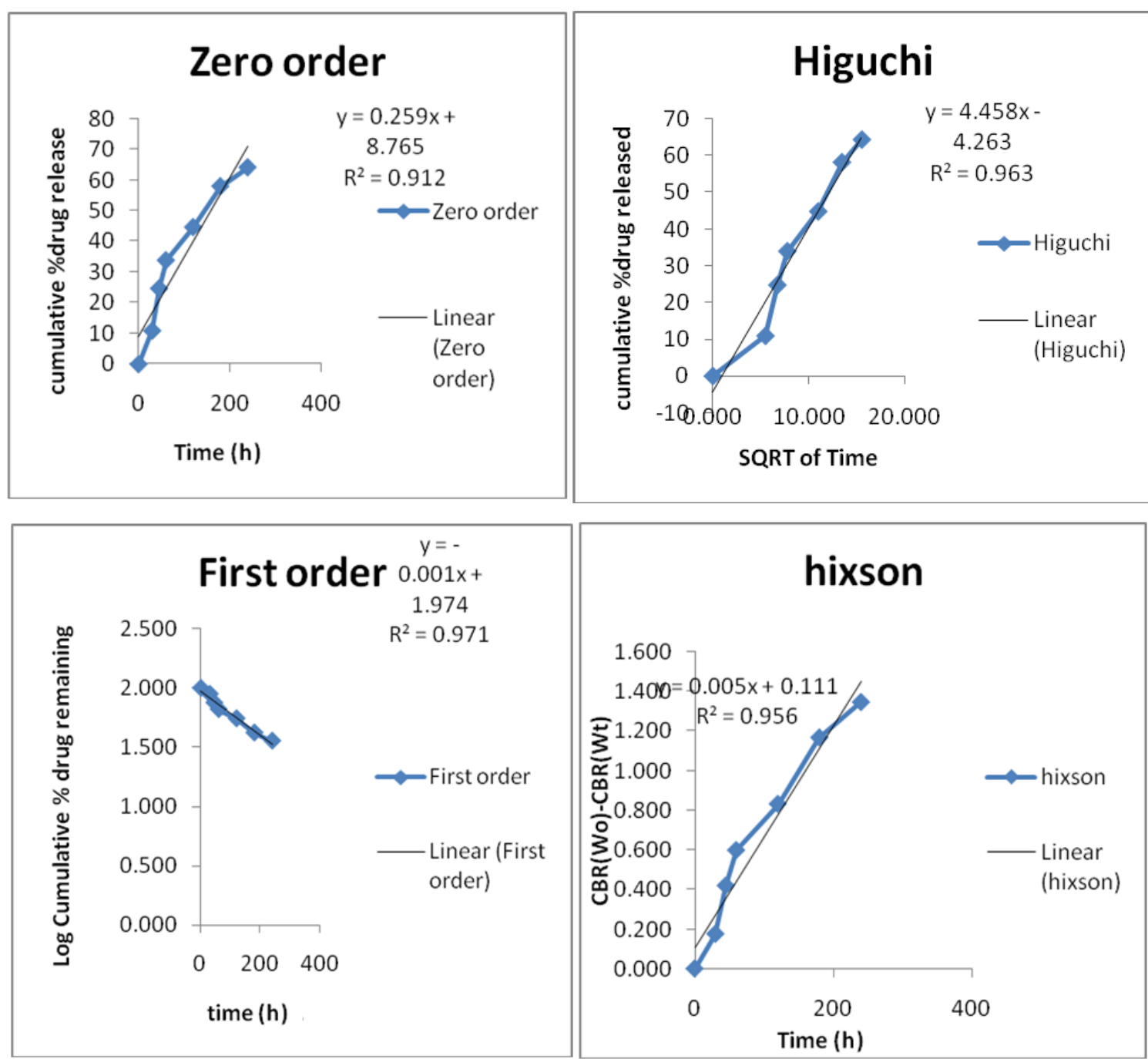

Fig. 11: Drug release kinetic of sustained release layer (diclofenac sodium)

\section{Kinetic models}

Dissolution data of above bi-layered tablet was fitted in Zero order, First order and Higuchi equations. The mechanism of drug release was determined by using Higuchi equation.

\section{CONCLUSION}

The prepared tablets showed satisfactory results for various evaluation tests such as tablet dimension, hardness, friability, weight uniformity, drug content and in vitro dissolution study. The optimized formulation based on all the parameter A1 (Sodium starch glycolate) is selected for the immediate release layer and D3 (HPMC K4M) was selected for the controlled release layer. The drug release mechanism was found to be zero order release; dependent on both drug diffusion and polymer relaxation. The bilayer tablets of Aloe vera gel powder and Diclofenac sodium useful for NSAID with antiulcer Aloe vera gel powder.

\section{ACKNOWLEDGMENT}

Authors are thankful to Vishal Institute Pharmaceutical Education and Research, Ale for providing the raw materials to carry out this research work successfully. 


\section{AUTHORS CONTRIBUTIONS}

All the author have contributed equally

\section{CONFLICT OF INTERESTS}

Declare none

\section{REFERENCES}

1. B Prabakaran, K Elango, K Ramesh Kumar, D Jaison. Formulation development and evaluation of gastroretentive bilayer floating tablets of simvastatin and telmisartan. Int J Pharma Res Rev 2016;5:9-18.

2. Prabhakar Shirse. Formulation and evaluation of bilayer tablets of diclofenac sodium with ranitidine HCL for sustained and immediate release. J Appl Pharm Sci 2012;2:136-41

3. https://en.wikipedia.org/wiki/Diclofenac. [Last accessed in 10 Mar 2019].
4. Bharath Kumar N, S Bharath, R Deveswaran, BV Basavaraj, V Madhavan, Extended drug release retarding effect of aloe vera gel in the design of tablet dosage form. IJPBS 2012;2:54-9.

5. Karthik Varma V. Excipients used in the formulation of the tablet. Res Rev J Chem 2016;5:143-5.

6. Lachman L, Lieberman HA, Kanig JL. The theory and practice of Industrial pharmacy, Varghese Publishing House Bombay; special Indian edition; 2009

7. Gurdeep R Chatwal, Sham K Anand. Instrumental methods of chemical analysis. 3rd ed Himalaya Publishing House, Mumbai; 2011. p. 244

8. Shivani Kala, Divya Juyal. Preformulation and characterization studies of aceclofenac active ingredient. Pharma Innovation J 2016;5:110-9.

9. Indian Pharmacopoeia. Ministry of Health and Family Welfare. Ghaziabad, India: The Indian Pharmacopoeia commission; 2010. p. 3.

10. United States Pharmacopoeia. $30^{\text {th }}$ edition NF 25-2007, The Official Compendia of Standards. 643, Pharmacopoeial forum; 2007. p. 28 